УДК 37.03

\author{
Людмила Іщценко, \\ доктор педагогічних наук, \\ професор кафедри психології та \\ педагогіки розвитку дитини \\ Уманського державного педагогічного \\ університету імені Павла Тичини
}

\title{
РОЗВИТОК ДОСЛІДНИЦЬКИХ ЗДІБНОСТЕЙ ДІТЕЙ ДОШКІЛЬНОГО ВІКУ
}

Стаття присвячена проблемі розвитку дослідницьких здібностей дітей дошкільного віку. Мета статті полягає у розкритті методики розвитку дослідницьких здібностей стариих дошкільників у розвивальному середовищі дошкільного закладу освіти. Встановлено, щзо важливою педагогічною умовою розвитку дослідницьких здібностей дітей дошкільного віку $\epsilon$ створення розвивального середовища в групі дошкільного закладу освіти. В основі методики навчання лежить застосування дослідницького методу. Головна роль відводиться прийомам розвитку досліднииьких умінь $і$ навичок, необхідних для здійснення дослідницької діяльності. Розвиток дослідницьких здібностей успішно здійснюеться в рамках спеціально організованого освітнього прочуесу дошкільного закладу освіти.

Ключові слова: розвиток дослідницьких здібностей, дослідницькі вміння, навички, почукова активність.

The article is devoted to the problem of development of research abilities of children of preschool age. The purpose of the paper is to uncover the methods of developing research abilities of senior preschool children in the developing environment of a preschool institution. It was found out that the important pedagogical condition of development of research abilities of children of preschool age is the creation of a developing environment in a group of preschool educational institutions. The basic principles that guided the development of the methodology were: high degree of independence of the child in the learning process; active research methods; principle of openness of tasks; a flexible combination of individual and collective forms of work. Found that the basis of research abilities is search activity. It acts as a motive that triggers the mechanism of research behavior. The developed methodology for the development of research skills of senior preschool children covers the following components: monitoring the development of research abilities of the child, development of research skills and skills in educational activities, 
organization of independent research practice, special classes on the development of intellectual and creative potential of children. The basis of the teaching methodology is the application of the research method. The main role is assigned to the development of research skills and skills necessary for research. The development of research abilities is successfully carried out within the framework of a specially organized educational process of the preschool educational institution.

Key words: development of research abilities, research skills, skills, search activity.

Відповідно до Закону України «Про освіту», Закону України «Про дошкільну освіту» пріоритетним напрямом реформування системи освіти $\epsilon$ iii особистісна орієнтація, а саме: формування активної й творчої особистості, яка здатна до успішної адаптації, прогресивних перетворень у житті суспільства. У документах також зазначено, що сучасна система освіти має створити умови для особистісного розвитку i творчої самореалізації кожного громадянина [2].

Проблема розвитку здібностей дітей дошкільного віку посідає чільне місце серед багатьох наук: психології, педагогіки, соціології та ін.

Універсальні дослідницькі здібності, серед яких найбільш значущими є здатність швидко орієнтуватися в ситуації, творчо підходити до вирішення проблем, уміння знаходити і аналізувати інформацію, дозволяють людині активно діяти, перетворювати і творити. Основи розвитку означених здібностей закладаються вже в дошкільному віці, який характеризується особливою чутливістю до засвоєння навколишньої дійсності та активністю дошкільника (пізнавальна, дослідницька, творча). 3 великим інтересом діти беруть участь у дослідницькій діяльності, у якій проявляють допитливість і бажання експериментувати.

Питанню розвитку дитячої творчості, винахідливості, пізнавальної активності присвятили свої праці Л. Венгер, Л. Виготський, О. Запорожець, Д. Ельконін, Г. Костюк, М. Поддьяков, С. Рубінштейн. Учені довели, що дошкільний вік $є$ сензитивним періодом у розвитку творчої особистості.

Такі вчені, як Н. Ветлугіна, В. Давидов, Т. Казакова, Т. Комарова досліджували прояви розвитку здібностей особистості в різних видах діяльності (музичній, мовленнєвій, ігровій, образотворчій). Це дало змогу визначити основні критерії проявів різноманітних нахилів та здібностей: прагнення до власної досконалості, до перетворення навколишньої дійсності, самостійність, оригінальність думок та ідей, гнучкість і варіативність.

У сучасних дослідженнях (I. Бех, А. Богуш, І. Булах, В. Гальченко,
I. Карабаєва,
В. Кузьменко,
В. Моляко,
Є. Панько,
Е. Помиткін, 
В. Рибалка, О. Скрипченко, В. Ямницький) доведено, що допитлива i творча думка народжується в дієвій мисленнєвій діяльності тоді, коли дитина відносно своїх знань займає активну життєву позицію. Тому вивчення мисленнєвої діяльності дошкільника, вміння майстерно зацікавити, пробудити допитливість, пізнавальний інтерес складають необхідне підгрунтя для формування допитливої, винахідливої та активної особистості.

У вітчизняній психології накопичений багатий досвід вивчення $\mathrm{i}$ формування орієнтовно-дослідницької діяльності. Ця проблема розроблялася П. Гальперіним, О. Запорожцем, М. Поддьяковим, В. Зінченко. Роботи цих учених дозволили виявити сутність, структуру, закономірності перебігу, а також значення орієнтовно-дослідницької діяльності для пізнавального розвитку дитини.

Проблема детермінації, структури, вікових особливостей дослідницької поведінки відображена у працях вітчизняних (М. Поддьяков, О. Савенков) і зарубіжних (Д. Берлайн, К. Хатт, А. Фей, Р. Глейзер, К. Хеллер та ін.) вчених. Вищезазначені роботи дозволяють відповісти на питання про психологічну сутність дослідницької діяльності i поведінки, особливості іiі детермінації зовнішніми і внутрішніми умовами, ролі дослідницької поведінки в пізнавальній активності дитини. Також ці роботи присвячені вивченню питання про психічні властивості та якості, які необхідні для успішного здійснення дослідницької діяльності.

Учені (М. Поддьяков, Л. Парамонова, М. Веракса, О. Савенков, В. Афанасьєва) зазначають, що методами дослідницької діяльності дошкільнят виступають експеримент, метод спроб і помилок, досвід та спостереження. Дослідження засвідчують, що дитяче експериментування можна розглядати як перетворюючу діяльність дошкільнят, у якій пізнаються якості й властивості об'єктів навколишнього світу. Тому дослідницька активність, як зазначає О. Савенков, - природний стан дитини, який створює дослідницька поведінка і забезпечує умови для того, щоб психічний розвиток дитини насамперед розгортався як процес саморозвитку. Пошукова активність дитини в спеціально організованих умовах може привести до появи психічного новоутворення, яке називають «дослідницькі здібності» [5].

На основі експериментальних даних Е. Торндайк [7] сформулював низку законів організації поведінки, заснованої на «пробах і помилках». Учений вважав, що можливі способи реагування на невпинно мінливі умови зовнішнього середовища не можуть бути заздалегідь передбачені у структурі й способах поведінки організму, тому узгодження цієї поведінки 3 середовищем реалізується тільки на ймовірній основі. Таким чином, принцип «спроб, помилок та випадкового успіху», згідно ідей Е. Торндайка, пояснює набуття живими істотами нових форм поведінки на 
всіх рівнях розвитку.

Французький педагог О. Декролі [1] великого значення надавав активності дитини у навчанні, у самостійному, дослідницькому пошуку. М. Монтессорі також акцентувала увагу на використанні чітко і вміло продуманої програми розвитку кожної дитини. Ця програма розрахована як на сьогоднішній день, так і на багато років вперед, органічно поєднуючи в собі навчання і виховання на основі пробудження та підтримки дитячої активності.

У вітчизняній психології накопичено велику низку досліджень в галузі психології здібностей. Ця проблематика відображена в роботах Б. Ананьєва, Л. Венгера, В. Дружиніна, М. Поддьякова. Так, М. Поддьякова. визначає дослідницьку поведінка, як поведінку, яка спрямована на пошук і набуття нової інформації із зовнішнього оточення. У цьому визначенні ключовим моментом $\epsilon$ «пошук інформації» [4], відповідно предметом дослідження тут виступають різні види діяльності, у яких основну або істотну роль відіграє пошук та отримання інформації із зовнішніх джерел.

Пошук інформації дійсно має пряме відношення до дослідницької поведінки, але не вичерпується нею. Тому в роботі дотримуємося визначення, яке дав О. Савенков [5]. Він розглядає дослідницьку поведінку як вид поведінки, яка побудована на базі пошукової активності й спрямована на вивчення об'єкта або нетипової (проблемної) ситуації. Учений вважає, що дослідницька поведінка $є$ невід'ємним проявом життєвої активності будь-якої живої істоти. Вона виконує найважливішу функцію - функцію розвитку, яка забезпечує адаптацію організму до динамічного зовнішнього оточення і в кінцевому результаті є гарантією виживання цього організму і виду в цілому.

У діяльності людини, на думку М. Поддьякова [4], дослідницька поведінка виступає як універсальна характеристика, що пронизує всі інші види діяльності. Вона виконує найважливіші функції у розвитку пізнавальних процесів всіх рівнів, а саме: у навчанні, у нагромадженні соціального досвіду, у розвитку особистості. Особливу роль педагог відводить дослідницькій поведінці в оволодінні новими, маловивченими галузями і видами діяльності.

Таким чином, в основі дослідницької поведінки лежить пошукова активність, яка актуалізується в умовах нестандартної ситуації, головною ознакою якої є об'єктивна неможливість задоволення звичайних потреб звичними способами.

Таким чином, дослідницькі здібності - це індивідуальнопсихологічні особливості особистості, які забезпечують успішність і якісну своєрідність процесу пошуку, набуття й осмислення нової інформації. В основі дослідницьких здібностей лежить пошукова активність. Вона 
виступає в якості мотиву, який стимулює механізми дослідницької поведінки.

Мета статті полягає у розкритті методики розвитку дослідницьких здібностей старших дошкільників у розвивальному середовищі дошкільного закладу.

Підгрунтям для розробки методики формування означеної якості у дошкільників є теоретичні положення вчених (Л. Венгера, М. Лейтеса, О. Леонтьєва, К. Платонова, С. Рубінштейна, Б. Теплова, В. Шадрикова), які сформульовані у дослідженнях з проблеми здібностей і дозволяють відповісти на питання про психологічну сутність і природу здібностей, їх структуру і типи, про провідні фактори їх формування і розвитку.

В основі методики навчання лежить застосування дослідницького методу, за допомогою якого діти, які перебувають у позиції дослідника, відкривають зв'язки і закономірності навколишнього світу. Головна роль відводиться прийомам розвитку дослідницьких умінь i навичок, які необхідні для здійснення дослідницької діяльності - це бачити проблему, висувати гіпотези, давати визначення, класифікувати, спостерігати, структурувати матеріал, робити висновки й узагальнення, доводити i захищати свої ідеї. Окрім цього, велике місце відводиться розвитку дивергентного мислення (швидкості, гнучкості, оригінальності, розробленості), конвергентного мислення, прийомам стимулювання допитливості й дослідницької активності.

Створена методика розвитку дослідницьких здібностей старших дошкільників охоплює такі компоненти:

- моніторинг розвитку дослідницьких здібностей дитини;

- розвиток дослідницьких умінь і навичок в освітній діяльності;

- організацію самостійної дослідницької практики;

- спеціальні заняття 3 розвитку інтелектуально-творчого потенціалу дітей. були:

Основними принципами, якими керувалися при розробці методики

- висока ступінь самостійності дитини у процесі навчання;

- активні методи навчання дослідницького характеру;

- принцип відкритості завдань;

- гнучке поєднання індивідуальних і колективних форм роботи.

Розроблена методика розвитку дослідницьких здібностей включає комплекс занять із основних напрямків роботи 3 дітьми в дошкільному закладі, а саме: «Світ природи», «Соціальний світ», «Розвиток мовлення», «Образотворча діяльність», «Конструювання і аплікація». Оптимальною структурою занять є поєднання традиційного викладу матеріалу 3 елементами дослідницької діяльності. Окрім цього вона передбачає спеціальні заняття з розвитку інтелектуально-творчого потенціалу дітей, 
які проводилися один раз на тиждень у вільний від основних занять час.

Одне з основних умінь, яке необхідне в дослідницькому пошуку, $є$ вміння бачити проблему. О. Савенков вважає, що вміння бачити проблему це інтегральна властивість, яка характеризує мислення людини, розвивається у різноманітних видах діяльності [5]. 3 огляду на це, у роботі 3 дітьми широко використовували спеціальні вправи та ігри. Наприклад:

Завдання «Подивіться на світ чужими очима». Дітям читають незакінчену розповідь, потім пропонується іï продовжити. Прийшов листопад. Пішов дощ зі снігом, стало холодно. На дорозі слизько. Продовж розповідь, уявивши, що ти...

- гуляєш у дворі;

- водій вантажівки і їдеш по дорозі;

- горобець, що сидить на гілці.

Цей прийом можна використовувати при складанні описових розповідей. Наприклад, дітям пропонують скласти описову розповідь про зиму від імені:

- дітей, які дуже чекали зиму;

- водія автобуса;

- старенької бабусі.

У процесі виконання завдання важливо прагнути до того, щоб діти були розкуті й відповідали сміливо. Необхідно заохочувати всі відповіді дітей.

Наступне завдання «Скільки значень у предмета», яке розроблене американським психологом Дж. Гілфордом [6]. Дітям показують будь-який знайомий предмет та пропонують назвати якнайбільше варіантів нетрадиційного, але реального використання цього предмета.

Також дітям дають завдання намалювати зиму і дати назву своєму малюнку. У процесі виконання цього завдання необхідно було виділити найрізноманітніші аспекти одного і того ж явища.

Одним із головних, базових умінь дослідника є вміння висувати гіпотези, в основі проявів яких лежить дивергентне мислення, а також такі особистісні якості, як самостійність, рішучість, наполегливість, критичність. Для тренування цього вміння використовують такі завдання:

Завдання «Пошук причин подій». Суть вправи полягає в тому, що дітям пропонують ситуаціі, у яких необхідно сформулювати можливі причини і наслідки описаних у них подій. Наприклад:

Ситуація «Сашко посипав доріжку навколо будинку піском».

Діти називають можливі причини, для чого потрібно посипати доріжку піском.

Іншим завданням для розвитку вміння висувати гіпотези є створення i розв'язання проблемних ситуацій. Ефективними вправами є завдання такого характеру: «Чим можуть бути корисні птахам такі предмети, як 
гілка дерева, фрукти, книга, телефон?».

Цікавим і ефективним прийомом розвитку вміння класифікувати $€$ прийом «класифікація з помилками». Використання означеного прийому робить заняття більш емоційними, цікавими, при цьому дозволяє пояснити правила класифікації предметів, об'єктів тощо.

Велике місце серед умінь, які необхідні у дослідницькому пошуку, займає вміння спостерігати. У психологічній літературі описані найрізноманітніші вправи і завдання для тренування цього вміння. Ось деякі з них:

Завдання «Парні картинки, що містять відмінності». Педагог показує дітям два майже однакових малюнка i пропонує знайти той, який відрізняється від іншого.

Гра «Художник». Суть гри полягає у тому, що дитина, яка отримує роль художника, має уважно подивитися на того, кого буде малювати, потім відвертається і дає його словесний опис. Діти намагаються відгадати, кого дитина описувала.

Для розвитку дивергентного мислення використовували завдання «Фантастична тварина». Дітям пропонують намалювати тварину, якої не існує на нашій планеті. Звертають увагу на те, що можна комбінувати різні тварини, створювати нові. У процесі виконання роботи не потрібно дітям підказувати або давати готові зразки, щоб вони не копіювали або малювати щось подібне. У кінці заняття необхідно дати можливість усім дітям розповісти про свою роботу і виділити найцікавіші та найоригінальніші 3 них.

Завдання «Жива пляма». Дітям пропонують зробити плями на альбомному аркуші, а потім домалювати будь-яке зображення. На початку заняття вихователі демонструють весь процес створення плям. Далі діти розглядають отриману пляму і називають на що вона схожа.

Завдання «Придумай нову кінцівку розповіді». Дітям читають розповідь, потім пропонують придумати нову кінцівку цього оповідання.

Завдання «Колаж». Дітям пропонують на альбомному аркуші наклеїти шматочки паперу, вирізані 3 кольорових журналів, потім розглянути зображення, яке виникло, і сказати на який предмет воно схоже. Розглядаючи колаж, необхідно уточнювати дітям, що його можна повертати як завгодно. Важливо, щоб вони могли побачити якомога більше предметів.

Найважливішим умінням будь-якого дослідника $\epsilon$ вміння організовувати і ставити експерименти. Експериментуванню в освітньому процесі дошкільного закладу відводиться особливе місце, так як це один 3 основних методів, що дозволяє дитині моделювати в своїй свідомості картину світу, засновану на власних спостереженнях, експериментах, встановленні взаємозалежностей, закономірностей. У навчально-виховному 
процесі дошкільного закладу були організовані як уявні експерименти, так i експерименти з реальними об'єктами.

В ході уявних експериментів дітям було запропоновано вирішити такі ситуації: що станеться, якщо:

- цієї осені дерева не скинуть листя;

- дощ йтиме цілий місяць;

- взимку мухи не ляжуть спати.

У процесі вирішення проблемних ситуацій необхідно спонукати дітей до того, щоб було висунуто якомога більше реальних ідей i простежувався весь ланцюжок подій, які можуть відбутися.

Найцікавішими є експерименти з реальними об'єктами. Наприклад: «Чому у водоплавних птахів такий дзьоб?». Мета експерименту: визначити зв'язок між будовою і способом життя птахів в екосистемі. Експеримент «3 водою і без води» спрямований на виділення факторів зовнішнього середовища, які необхідні для росту і розвитку рослин (вода, світло, тепло).

У процесі експериментування необхідно давати можливість кожній дитині бути в ролі експериментатора, спонукати дітей до самостійного пошуку оптимального вирішення проблеми, формулювання висновків i умовиводів.

Необхідною умовою розвитку дослідницьких здібностей $\epsilon$ організація самостійної дослідницької діяльності дітей. Тематика досліджень може бути різноманітна, зокрема: «сніг», «вода», «повітря», «кімнатні рослини», «домашні і дикі тварини» тощо.

Найважливіша якість, яка вимагається при обробці матеріалів, здобутих в ході дослідження - це вміння аналізувати. Як відомо, будь-яке дослідження закінчується формулюванням висновків і узагальнень. Уміння робити висновки вимагає від дитини узагальнення i структурування матеріалу, який отриманий у ході дослідження. Для розвитку і тренування цього уміння пропонували дітям такі завдання: «На що схоже». Дітям показують малюнки 3 зображеннями різних кімнатних і польових квітів (кактус, ромашка, дзвіночок, півники) і запитують, на які предмети вони схожі. При виконанні завдання звертають увагу, щоб діти аргументували свою відповідь.

Варіанти відповідей дітей: «Кактус схожий на дерево, бо він має такий же товстий стовбур, на їачка, тому що такий же колючий», «Ромашка схожа на сонечко, тому що вона кругла і з пелюстками, як у сонечка».

Таким чином, розроблена система методів і засобів навчання стимулювала розвиток дослідницьких здібностей дітей старшого дошкільного віку.

Встановлено, що в основі дослідницьких здібностей лежить 
пошукова активність. Вона виступає в якості мотиву, що запускає механізм дослідницької поведінки.

Відтак, робота із розвитку дослідницьких здібностей дітей старшого дошкільного віку включала такі напрямки: моніторинг розвитку дослідницьких здібностей, стимулювання допитливості, схильності до експериментування, розвиток дослідницьких умінь і навичок в освітній діяльності, розвиток дивергентного мислення, організацію самостійної дослідницької практики дітей.

Отже, особливістю розробленої методики є те, що ії використання забезпечує поступальний розвиток дослідницьких здібностей у дошкільнят та їхнього дослідницького потенціалу в розвиваючому середовищі дошкільного закладу. Натомість, ще не всі окреслені у статті завдання розв'язані, оскільки означена проблема багатоаспектна і багатогранна. Завданням подальших наукових досліджень вбачаємо дослідження наступності в роботі 3 розвитку дослідницьких здібностей старших дошкільників та першокласників.

\section{СПИСОК ВИКОРИСТАНИХ ДЖЕРЕЛ}

1. Дичківська I. М. Інноваційні педагогічні технології : навч. посіб. / I. М. Дичківська. - К. : Академвидав, 2004. - 352 с.

2. Закон України «Про дошкільну освіту» // Законодавчі акти України 3 питань освіти. Станом на 01.04.04 p. - К., 2004. - С. 53-77.

3. Монтессори М. Разум ребенка / Мария Мотессори // Помоги мне это сделать самому / М. Монтессори ; сост., вступ. статья М.В.Богуславский, Г.Б.Корнетов. - М. : ИД «Карапуз», 2000. C. $85-188$.

4. Поддъяков Н. Н. Исследовательское поведение: стратегии познания, помощь, противодействие, конфликт / Н. Н. Поддъяков. - М. : Б.и., 2000. $-266 \mathrm{c}$.

5. Савенков А.И. Путь к одаренности: исследовательское поведение дошкольников / А. И. Савенков. - СПб. : Питер, 2004. - 272 с.

6. Guilford J. The nature of human intelligence / J. Guilford. - New York : Mc. Grew Hill, 1967. - 207 p.

7. Thorndike E. Animal intelligence I E. Thorndike II New York, 1911. 